\title{
Ketone bodies metabolism during ischemic and reperfusion brain injuries following bilateral occlusion of common carotid arteries in rats ${ }^{1}$
}

\author{
Metabolismo dos corpos cetônicos durante as lesões de isquemia e reperfusão \\ cerebrais após oclusão bilateral das artérias carótidas comuns em ratos
}

\author{
Mário Henrique Girão Faria ${ }^{2}$, Luis Roberto Franklin Muniz ${ }^{3}$, Paulo Roberto Leitão de Vasconcelos ${ }^{4}$ \\ 1. Research performed at Experimental Surgery Laboratory (LABCEX), Department of Surgery, Federal University of Ceará Medical \\ School, Brazil. \\ 2. MD, Fellow PhD degree, Department of Physiology and Pharmacology, Federal University of Ceará Medical School, Brazil. \\ 3. MD, Neurosurgeon, Dr. José Frota Institute (IJF), Fortaleza, Ceará, Brazil. \\ 4. PhD, Associate Professor, Coordinator of Post-Graduation Program in Surgery, Department of Surgery, Federal University of Ceará \\ Medical School, Brazil.
}

\begin{abstract}
Purpose: To evaluate the in vivo alterations on ketone bodies metabolism after cerebral ischemia/reperfusion through an experimental model of brain ischemia induced by simple occlusion of common carotid arteries (CCAs) in Wistar rats. Methods: Forty-eight male Wistar rats were randomly distributed on two groups ( $\mathrm{S}-\mathrm{Sham}$; $\mathrm{T}$-Test) and further redistributed into four times sets of study. After bilateral occlusion of CCAs for 30min, the animals of group T were allowed reperfusion for $0,5,10$ and $15 \mathrm{~min}$. Samples of cerebral tissue and systemic arterial blood were collected and the metabolites acetoacetate (ACT) and beta-hydroxybutyrate (BHB) were determined. Results: Cerebral ACT and BHB levels increased significantly in Group $\mathrm{T}$ after 30min of carotid occlusion (time 0 ). The highest brain ketone bodies (ACT+BHB) concentration was verified at $5 \mathrm{~min}$ of reperfusion, decreasing after $10 \mathrm{~min}$ of recirculation. Systemic ketone bodies levels increased similarly between test and sham groups. Group S demonstrated a significant increase in cerebral and systemic ACT and BHB concentrations mainly after $40-45 \mathrm{~min}$ of study. Conclusions: The partial transient acute global brain ischemia induced by the bilateral carotid occlusion in Wistar rats triggered ketogenesis probably due to a central stimulation of catecholamine secretion. There was an increased cerebral uptake of ketone bodies following brain ischemia, reaffirming these metabolites as alternative energy substrates under conditions of cerebral metabolic stress as well as its potential role on neuroprotection. The greatest changes in ketone bodies metabolism were verified at initial minutes of recirculation as a result of the reperfusion injury phenomenon.
\end{abstract}

Key words: Brain ischemia. Reperfusion. Ketone bodies. Metabolism. Rats.

\section{RESUMO}

Objetivo: Avaliar as alterações in vivo no metabolismo dos corpos cetônicos após isquemia/reperfusão cerebral através de um modelo experimental de isquemia cerebral induzido pela simples oclusão das artérias carótidas comuns (CCAs) em ratos Wistar. Métodos: Quarenta e oito ratos Wistar machos foram distribuídos aleatoriamente em dois grupos (S Controle; T - Teste) e cada um deles redistribuídos em quatro tempos de estudos. Após oclusão bilateral das CCAs por $30 \mathrm{~min}$, permitiu-se reperfusão aos animais do grupo T nos tempos 0, 5, 10 e $15 \mathrm{~min}$. Foram coletadas amostras de tecido cerebral e sangue arterial sistêmico e quantificados os metabólitos acetoacetato (ACT) e beta-hidroxibutirato (BHB). Resultados: Os níveis cerebrais de ACT e BHB aumentaram significantemente no Grupo T após 30min de oclusão carotídea (tempo 0). A maior concentração de corpos cetônicos (ACT+BHB) foi verificada aos $5 \mathrm{~min}$ de reperfusão, diminuindo após 10min de recirculação. Os níveis de corpos cetônicos sistêmicos aumentaram de modo semelhante entre os grupos teste e controle. O Grupo S demonstrou significante aumento nas concentrações sistêmicas e cerebrais de ACT e BHB principalmente após 40-45min de estudo. Conclusões: A isquemia cerebral aguda transitória e parcial induzida pela oclusão bilateral das carótidas em ratos Wistar ativou a cetogênese provavelmente devido à estimulação central da secreção de catecolaminas. Houve um aumento da captação dos corpos cetônicos após isquemia cerebral, reafirmando esses metabólitos como substratos energéticos alternativos em condições de estresse metabólico cerebral, bem como suas potencialidades na neuroproteção. As maiores alterações no metabolismo dos corpos cetônicos foram verificadas nos minutos iniciais de recirculação como resultado do fenômeno da lesão de reperfusão.

Descritores: Isquemia cerebral. Reperfusão. Corpos cetônicos. Metabolismo. Ratos. 


\section{Introduction}

Stroke is the third leading cause of death in the world. Ischemic stroke represents the main cause of death and disability among elderly people. Most stroke survivors are left with lifelong disability. ${ }^{1}$ At present, only recombinant tissue plasminogen activator (rt-PA) has been efficiently labeled for the management of acute stroke. ${ }^{2}$ Understanding the role of various extrinsic and intrinsic pathogenic factors of ischemic damage represents a prime objective of ongoing stroke research. The development of experimental models of cerebral ischemia has allowed for a better knowledge of its pathophysiology and for testing new therapeutic strategies. ${ }^{3}$ In this direction, diverse rodent models of brain ischemia/ reperfusion have been proposed. ${ }^{4}$ The two-vessel occlusion model is easier to perform, and the less-intrusive surgical intervention allows greater scope for recovery experiments. However, some previous studies reported failure of this model in the attainment of the ischemic event in rats, justified for the rich and extensive collateral circulation through the circle of Willis, the end-to-end anastomosis and the cortical branches from the internal and external carotid system in these animals. ${ }^{5}$ Despite this, we recently described some metabolic alterations in glycolysis and oxidative phosphorylation pathways in an experimental model of brain ischemia induced only by the bilateral occlusion of common carotid arteries in rats. This approach was based on the evidences that glucose is the main substrate that fulfills energy brain demands. ${ }^{6}$ Nevertheless, some evidences indicate that brain may utilize the ketone bodies (KB), acetoacetate (ACT) and beta-hydroxybutyrate (BHB), as alternative energy substrates under conditions of cerebral metabolic stress. Ketone body utilization in brain depends directly on its blood concentration, which is normally very low, however can increases substantially during extreme injuries (trauma, stroke, hypoxia). The major site of production of KB is the liver, where these substances diffuse to the blood and are transported to peripheral tissues. Cerebral KB metabolism is regulated by the permeability of the blood-brain barrier, which depends on the abundance of monocarboxylic acid transporters. Monocarboxylic acid transporters are present in the plasma membranes of neurons and glia but their role in regulating $\mathrm{KB}$ metabolism is uncertain. Finally, the rate of cerebral KB metabolism depends on the activities of the relevant enzymes in brain. ${ }^{7}$ The aim of the present study was to evaluate the in vivo alterations on ketone bodies metabolism after cerebral ischemia/reperfusion through an experimental model of brain ischemia by the simple occlusion of common carotid arteries in rats.

\section{Methods}

\section{Animals}

Forty-eight healthy male albino Wistar rats (Mammalia Rodentia, Muridae, Rattus norvegicus albinus) obtained from Federal University of Ceará Central Bioterium, weighing
$406.23 \pm 52.21 \mathrm{~g}$, were used in this study. All animals were of the same breed and maintained in controlled environment for research use only. All rat procedures and handling were in compliance with the ethical guidelines for handling and care of experimental animals according to Council for International Organization of Medical Sciences (CIOMS-WHO). Approval for experimental use of laboratory animals was obtained from Federal University of Ceará Commission of Ethics in Animal Research.

\section{Study design}

Animals were randomly and equitably distributed in two groups (24 rats each): Group S (sham) and Group T (test). Each group was redistributed into four subgroups (6 rats each), according to the different times sets of study. Animals from Group $\mathrm{T}$ were submitted to all surgical procedures, including the bilateral occlusion of common carotid arteries (CCAs) for $30 \mathrm{~min}$, followed by 0 (zero), 5, 10 and 15 minutes of reperfusion. Animals from Group $\mathrm{S}$ were submitted to all surgical procedures, except the bilateral occlusion of CCAs, and studied in equivalent set times of Group T.

\section{Surgical procedures}

All procedures were performed under anesthesia, consisting in the association of ketamine chlorhydrate (90 $\mathrm{mg} / \mathrm{Kg})$ and xylazin $(10 \mathrm{mg} / \mathrm{kg})$ administered into the intraperitoneal cavity. Initially, a frontal midline cervicotomy was performed and CCAs were carefully exposed and isolated from the surrounding connective tissues and nerve fibers. Rats of Group T were submitted to the simultaneous bilateral clamping of CCAs for 30min using aneurismal clips, while the animals of Group S only had the bilateral isolation of CCAs (without occlusion) for the same time. After this, a frontal midline laparotomy followed by dissection and isolation of abdominal aortic artery for later central arterial blood punction was effectuated. At last, an extensive craniectomy using a dual-face flexible abrasive wheel connected to an electrical micromotor at 20,000rpm for osteotomy was performed, then exposing the cerebral hemispheres. ${ }^{6}$

\section{Brain and blood samples}

Samples from cerebral tissue (left hemisphere, randomly chosen) and central arterial blood (abdominal aorta) were collected at the end of ischemia (time 0) and 5, 10 and 15 minutes after the aneurismal clips opening (reperfusion). In sham-operated rats, these samples were obtained after 30 , 35,40 and 45 minutes after the bilateral isolation of CCAs (without occlusion) according to pre-established set times of study. Brain samples were immediately frozen in liquid nitrogen for posterior biochemical analysis. Blood samples were placed in glass vials containing $10 \%$ perchloric acid and deep frozen until utilized. 


\section{Biochemical analysis}

Acetoacetate (ACT) and beta-hydroxybutyrate (BHB) concentrations were assayed in brain and blood samples according to biochemical methods published elsewhere. ${ }^{8}$

\section{Statistical analysis}

Ketone bodies (ACT, BHB and $\mathrm{ACT}+\mathrm{BHB}$ ) concentrations were calculated as $\mu \mathrm{mol} / \mathrm{g}$ of fresh brain tissue or $\mu \mathrm{mol} / \mathrm{mL}$ of blood and the results were expressed as median of different groups. Mann-Whitney nonparametric test (U test) was used for statistical analysis. Statistical significance was accepted as $\mathrm{p}<0.05$.

\section{Results}

Systemic ACT concentrations increased significantly in Group T after 30min of bilateral occlusion of CCAs (133.3\% time 0 ) and at $5 \mathrm{~min}$ of reperfusion (more $78.6 \%$ ), decreasing at 10 min of recirculation (42.7\%). Group S presented significant augmentation of systemic ACT (78.4\%) only after $45 \mathrm{~min}$ $(30+15 \mathrm{~min})$ of surgical procedures (Figure 1). Blood BHB concentrations remained low at 0 and $5 \mathrm{~min}$ of reperfusion, but showed significant increasing at $10(97.4 \%)$ and 15 minutes (more $41.5 \%$ ) of recirculation. Sham group demonstrated a significant and permanent increase of systemic BHB (145.9\%) after $35 \mathrm{~min}(30+5 \mathrm{~min})$ of surgical manipulation (Figure 2$)$. The joint analysis $(\mathrm{ACT}+\mathrm{BHB})$ showed a significant and similar increasing of systemic KB levels in Group $\mathrm{T}$ and Group $\mathrm{S}$, except for the higher $\mathrm{KB}$ concentrations at $10 \mathrm{~min}$ of reperfusion when compared with sham group (Figure 3). Cerebral ACT levels increased significantly in Group $\mathrm{T}$ after 30min of carotid occlusion (204.2\% - time 0 ) and at 5 min of reperfusion (more $152.0 \%$, followed by a significant reduction at $10(76.6 \%)$ and 15 minutes (more 32.5\%) of recirculation. This significant decrease at 15 minutes of reperfusion was of $83.8 \%$ when compared with Group S. At this time, sham group displayed significant increase of brain ACT concentrations after 10 (206.4\%) and 15 minutes (more $88.4 \%$ ) of reperfusion (Figure 1). Cerebral BHB concentrations showed a significant augmentation immediately after $30 \mathrm{~min}$ of clamping $(1,146.1 \%)$ proceeded by a significant decrease to control levels at $5 \mathrm{~min}$ of reperfusion. Group S presented a significant increase of cerebral BHB concentrations (192.3\%) only after $45 \mathrm{~min}$ of surgical procedures compared with its initial levels (30min time 0) (Figure 2). The combined analysis (ACT+BHB) demonstrated a significant elevation of brain $\mathrm{KB}$ concentrations in Group T after 30min of carotid clamping and at $5 \mathrm{~min}$ of recirculation (mean of $869.2 \%$ ) compared with the respective controls (Group S). Subsequently, we observed a significant decreasing of KB levels at $10(37.0 \%)$ and 15 minutes (more 53.8\%) of reperfusion when compared with the median concentration verified at $5 \mathrm{~min}$ of recirculation. Sham group also demonstrates a significant increase of cerebral KB levels (mean of $392.3 \%$ ) after $40-45 \mathrm{~min}$ of surgical procedures compared with its previous levels (Figure 3 ).

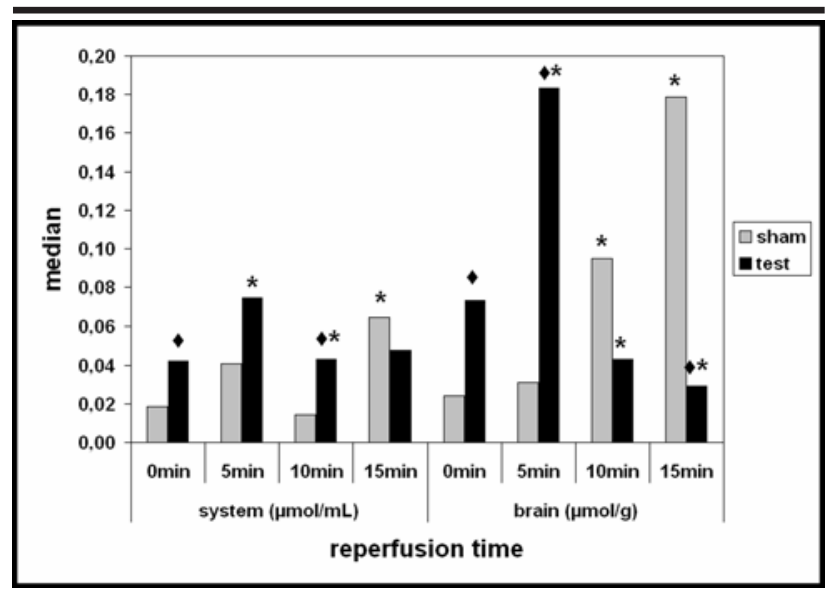

FIGURE 1 - Systemic and brain acetoacetate (ACT) concentrations in sham and test groups at different times of reperfusion. [*] $\mathrm{p}<0.05$ compared with respective sham group; [*] $\mathrm{p}<0.05$ compared with similar previous group (Mann-Whitney U test)

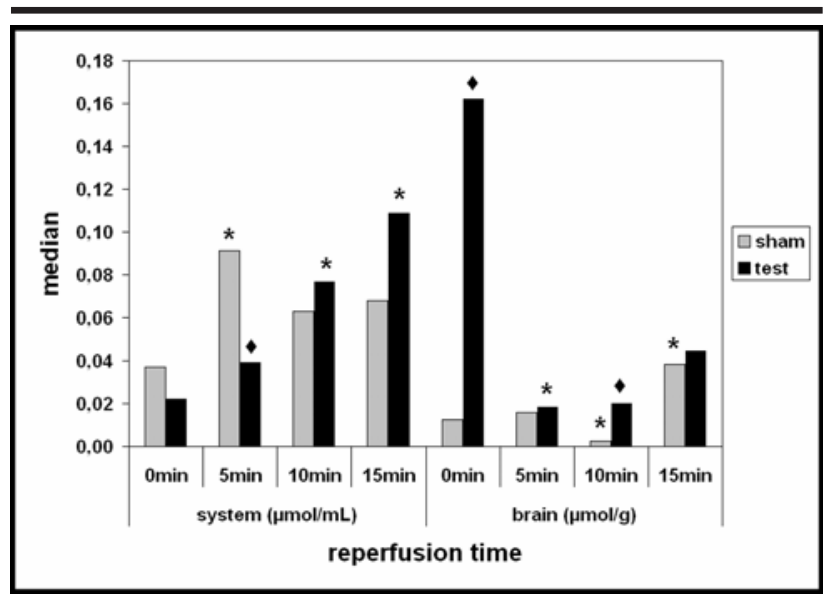

FIGURE 2 - Systemic and brain beta-hydroxybutyrate (BHB) concentrations in sham and test groups at different times of reperfusion. [ $\left.{ }^{\bullet}\right] \mathrm{p}<0.05$ compared with respective sham group; [*] $\mathrm{p}<0.05$ compared with similar previous group (Mann-Whitney $U$ test)

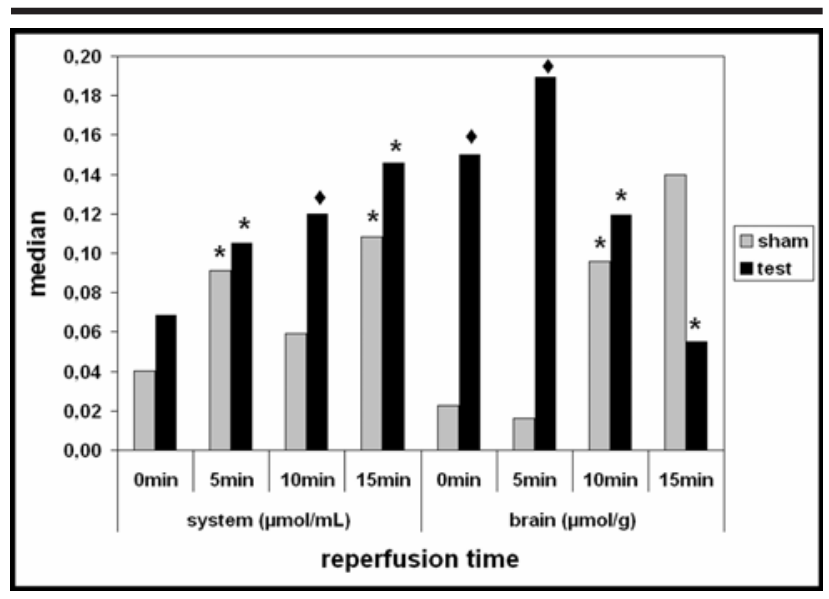

FIGURE 3 - Systemic and brain ketone bodies (ACT+BHB) concentrations in sham and test groups at different times of reperfusion. $\left[{ }^{\bullet}\right] \mathrm{p}<0.05$ compared with respective sham group; [*] $\mathrm{p}<0.05$ compared with similar previous group (Mann-Whitney $U$ test) 


\section{Discussion}

Although some of the biochemical effects of acute stress, including stroke, have been well described, relatively little attention has been directed towards possible changes on ketone bodies metabolism. Ketone bodies (KB) are an important source of energy for the brain and the rate of cerebral $\mathrm{KB}$ metabolism depends primarily on the concentration in blood. Acetoacetate (ACT) is derived from exceeding acetyl CoA, formed in fatty acid oxidation, and beta-hydroxybutyrate (BHB) is produced by the reduction of ACT. ${ }^{7}$ The current knowledge about stress metabolism considers that ketogenesis usually decreased immediately after an acute injury. The mechanism by which this is achieved is not completely understood, but appears to be related to increased insulin/glucagons concentrations triggered by inflammatory mediators, especially IL-1. ${ }^{9}$ On the other hand, in a subacute/chronic phase of stress, enhanced glycolysis in injured tissues promotes higher insulin utilization (decreased insulin resistance), diminishing plasma insulin concentration and then activating the ketogenesis. ${ }^{7-9}$ Despite this, our results demonstrated an increase of the systemic ACT concentrations immediately after 30min of bilateral occlusion of CCAs in rats (time 0 ), indicating that the occurrence of cerebral hypoperfusion was capable of triggering the hepatic synthesis of ACT. As far as literature as reviewed up to present moment, this appears to be the first experimental demonstration of ketogenesis activation after acute brain injury. Tamaki et al. ${ }^{10}$, studying the acute biochemical changes after severe head-injury, also evidenced increased plasmatic KB concentrations in patients, suggesting that this finding was likely due to the elevation of catecholamine levels. Moreover, those authors correlated the degree of ketonemia to the severity of head injury. Keller et al. ${ }^{11}$ demonstrated that the hyperketonemic effect of elevated plasma norepinephrine concentrations results from a combination of three factors: increased ketone body production from augmented fee fatty acids (FFA) supply to the liver; accelerated hepatic ketogenesis; and modestly decreased metabolic clearance of ketone bodies. At this time, Hakanson et al. ${ }^{12}$ founded that the epinephrine infusion induced increases in systemic FFA and KB levels more marked than those seen during and immediately after surgery. These findings corroborated to the CutherbertsonBessman's hypothesis of stress response, which postulate that acute stress reaction has two of phases, the catecholamine phase and the pituitary-adrenal phase. It is considered that the reaction to stress in the acute phase is due to glycogenolysis i.e., glucose from glycogen and lipolysis i.e., ketones from fat induced by catecholamine (so-called "flow phase" of the metabolic response to injury), and that increased ketone bodies and glucose levels in the subacute phase are due to ketogenesis and gluconeogenesis. ${ }^{13}$ Despite the insufficient published data to compare with the present results, the authors suggest that acute global brain ischemia in rats following bilateral carotid occlusion may triggers ketogenesis possibly due to a central stimulation of catecholamine secretion. Moreover, the increased cerebral levels of ACT and BHB after 30min of bilateral clamping of CCAs denoted the avidity of injured brain tissues to utilize these substances for the energy metabolism, as glucose alternative substrates, and also indicated that the ischemic event was partial, since the carotid occlusion not blocked cerebral KB uptake. The rich and extensive collateral circulation observed in rats as well as the post-ischemic enhancement of the blood-brain barrier permeability indeed may explain this finding, reinforcing the occurrence of brain ischemia followed by reperfusion. ${ }^{4-6}$ Recent studies also have been pointed ACT and BHB as cerebral function improving agents during hypoxia, anoxia and ischemia in rats and humans, confirming the importance of $\mathrm{KB}$ to neuroprotection and amelioration of brain damages. ${ }^{14}$ Interestingly, the concomitant increasing of systemic and cerebral ACT concentrations after carotid clamping was not verified with $\mathrm{BHB}$ levels: blood BHB concentration was initially low, despite its high cerebral levels. This was probably due to the initial system mobilization of ACT, which was quickly dispatched to the ischemic brain tissues and, only after that, locally reduced to BHB. It can be also suggested that this phenomenon may partially elucidates the intriguing similarity of systemic KB levels between test and sham group, since lower blood BHB concentrations than expected for Group T apparently soften the metabolic variations induced by brain injury to non-ischemic levels. The highest cerebral KB concentrations were verified after $5 \mathrm{~min}$ of reperfusion, mainly due to the augmentation of brain ACT, indicating that the more important metabolic brain alterations was probably occurring at this time. In our previous report, the authors also evidenced this trend and attributed this finding to the effects of reperfusion injury, when the absence of oxygen and energy metabolites creates a condition in which the restoration of circulation results in inflammation and oxidative damage rather than restoration of normal function. ${ }^{15}$ Despite this, cerebral ACT and BHB levels decreased after 10min of recirculation, suggesting that ischemic and reperfusion injuries were transitory and that the glucosebased energy metabolism was probably recovered, at last partially, following later reperfusion. On the other hand, there was an increase in cerebral and systemic ACT and BHB concentrations mainly after 40-45min of study in sham groups, equalizing systemic and cerebral $\mathrm{KB}$ levels in Group $\mathrm{S}$ to those observed in Group $\mathrm{T}$ at the corresponding set times. This may demonstrates a subacute enhancement of ketogenesis in nonischemic rats, due to surgical stress induced by the extended experimental procedures (mainly the craniectomy), possibly explained by the same biochemical mechanisms as those of ischemia/reperfusion cerebral injury, but triggered at a later time. $^{13}$

\section{Conclusions}

- Partial transient acute global brain ischemia following bilateral carotid occlusion in Wistar rats triggered ketogenesis probably due to a early central stimulation of catecholamine secretion;

- There was an increased cerebral uptake of ketone bodies 
(acetoacetate and beta-hydroxybutyrate) following brain ischemia, reaffirming these metabolites as alternative energy substrates under conditions of cerebral metabolic stress as well as its potential role on neuroprotection;

- The greatest changes in ketone bodies metabolism were verified at initial minutes of recirculation, characterizing the reperfusion injury phenomenon;

\section{References}

1. Thom T, Haase N, Rosamond W, Howard VJ, Rumsfeld J, Manolio T, Zheng ZJ, Flegal K, O’Donnell C, Kittner S, Lloyd-Jones D, Goff DC Jr, Hong Y, Adams R, Friday G, Furie K, Gorelick P, Kissela B, Marler J, Meigs J, Roger V, Sidney S, Sorlie P, Steinberger J, WasserthielSmoller S, Wilson M, Wolf P. American Heart Association Statistics Committee and Stroke Statistics Subcommittee. Heart disease and stroke statistics - 2006 update: a report from the American Heart Association Statistics Committee and Stroke Statistics Subcommittee. Circulation. 2006;113(6):e85151.

2. Martinez-Vila E, Irimia P. Challenges of neuroprotection and neurorestoration in ischemic stroke treatment. Cerebrovasc Dis. 2005;20 Suppl 2:148-58.

3. Alonso de Lecinana M, Diez-Tejedor E, Carceller F, Roda JM. Cerebral ischemia: from animal studies to clinical practice. Should the methods be reviewed? Cerebrovasc Dis. 2001;11 Suppl 1:20-3.

4. Traystman RJ. Animal models of focal and global cerebral ischemia. ILAR J. 2003;44(2):85-95.

5. McBean DE, Kelly PA. Rodent models of global cerebral ischemia: a comparison of two-vessel occlusion and four-vessel occlusion. Gen Pharmacol. 1998;30(4):431-4.

6. Muniz LRF, Faria MHG, Vasconcelos PRL. Avaliação metabólica das lesões de isquemia e reperfusão cerebrais após oclusão bilateral das artérias carótidas comuns: estudo experimental em ratos. Acta Cir Bras. 2004;19(5):529-34.

7. Morris AA. Cerebral ketone body metabolism. J Inherit Metab Dis. 2005;28(2):109-21.

8. Hohorst HJ, Kreutz FH, Buecher T. On the metabolite content and the metabolite concentration in the liver of the rat. Biochem Z. 1959;332:18-46.

9. Memon RA, Feingold KR, Moser AH, Doerrler W, Adi S, Dinarello CA, Grunfeld C. Differential effects of interleukin-1 and tumor necrosis factor on ketogenesis. Am J Physiol. 1992;263(2 Pt 1):E301-9.

10. Tamaki T, Shibata Y, Node Y, Yamamoto Y, Teramoto A. Metabolic acidosis and ketone body in severely head-injured patients. No Shinkei Geka. 2000;28(7):623-9.

11. Keller U, Lustenberger M, Muller-Brand J, Gerber PP, Stauffacher W. R Human ketone body production and utilization studied using tracer techniques: regulation by free fatty acids, insulin, catecholamines, and thyroid hormones. Diabetes Metab Rev. 1989;5(3):28598.

12. Hakanson E, Rutberg H, Jorfeldt L. Effect of adrenaline on exchange of free fatty acids in leg tissues and splanchnic area. A comparison with the metabolic response to surgical stress. Clin Physiol. 1986;6(5):453-63.

13. Griffiths RD, Hinds CJ, Little RA. Manipulating the metabolic response to injury. $\mathrm{Br}$ Med Bull. 1999;55(1):181-95.

14. Suzuki M, Suzuki M, Sato K, Dohi S, Sato T, Matsuura A, Hiraide A. Effect of beta-hydroxybutyrate, a cerebral function improving agent, on cerebral hypoxia, anoxia and ischemia in mice and rats. Jpn J Pharmacol. 2001;87(2):143-50.

15. Khalil AA, Aziz FA, Hall JC. Reperfusion injury. Plast Reconstr Surg. 2006;117(3):1024-33.

\section{Correspondence:}

Mário Henrique Girão Faria

Av. Benjamim Brasil, 1080 4/102

60712-000 Fortaleza-CE Brazil

Phone: (55 85)3467-0457

Fax:(55 85)3267-3840

mariofaria@doctor.com
Conflict of interest: none Financial source: none

Received: November 24, 2006

Review: December 19, 2006

Accepted: January 10, 2007

\section{How to cite this article:}

Faria MHG, Muniz LRF, Vasconcelos PRL. Ketone bodies metabolism during ischemic and reperfusion brain injuries following bilateral occlusion of common carotid arteries in rats. Acta Cir Bras. [serial on the Internet] 2007 Mar-Apr;22(2). Available from URL: http://www.scielo.br/acb 